Article

\title{
Critical Temperature and Pressure Conditions of Degradation during Thermochemical Hydrogen Compression: A Case Study of V-Based Hydrogen Storage Alloy
}

\author{
Fangqin Guo ${ }^{1}$, Ankur Jain ${ }^{2, *}{ }^{\infty}$, Hiroki Miyaoka ${ }^{2}$, Yoshitsugu Kojima ${ }^{2}$ and \\ Takayuki Ichikawa ${ }^{3, *}$ \\ 1 Graduate School of Integrated Arts and Science, Hiroshima University, Higashi-hiroshima 739-8521, Japan; \\ fang-qin-guo@hiroshima-u.ac.jp \\ 2 Natural Science Centre for Basic Research \& Development, Hiroshima University, \\ Higashi-hiroshima 739-8530, Japan; miyaoka@h2.hiroshima-u.ac.jp (H.M.); kojimay@hiroshima-u.ac.jp (Y.K.) \\ 3 Graduate School of Engineering, Hiroshima University, Higashi-hiroshima 739-8527, Japan \\ * Correspondence: ankur.j.ankur@gmail.com (A.J.); tichi@hiroshima-u.ac.jp (T.I.)
}

Received: 13 April 2020; Accepted: 2 May 2020; Published: 7 May 2020

\begin{abstract}
Disproportionation and phase separation are big issues that occur under extreme pressure and temperature conditions during hydrogen compressor cycles, which makes metal hydrides inactive and reduces compression efficiency. It is important to identify boundary conditions to avoid such unwanted phase separation. However, no investigation related to this problem has been carried out so far. Thus we propose a method to investigate the critical temperature and pressure condition for the alloy degradation during the hydrogen compressor cycle. The $\mathrm{V}_{20} \mathrm{Ti}_{32} \mathrm{Cr}_{48}$ alloy was chosen as a model system for the purpose. The influence of two important parameters (i.e., hydrogen content and temperature) was investigated individually. The disproportionation of $\mathrm{V}_{20} \mathrm{Ti}_{32} \mathrm{Cr}_{48}$ alloy during the hydrogen compressor cycle test occurred at temperatures higher than $200{ }^{\circ} \mathrm{C}$ and $75 \% \mathrm{H}_{2}$ content of the total capacity at the initial condition. A clear and obvious boundary condition between disproportionation and keeping the initial phase intact is defined herein. It can be treated as a general method for any hydrogen storage alloy to be utilized for hydrogen compressor efficiently and safely.
\end{abstract}

Keywords: disproportionation; $\mathrm{BCC}$ alloys; hydrogen compressor; $\mathrm{V}_{20} \mathrm{Ti}_{32} \mathrm{Cr}_{48}$

\section{Introduction}

Hydrogen compression based on reversible thermal energy-driven interaction of hydrogen storage materials with hydrogen gas has been developed as a promising option for hydrogen energy systems [1]. It works only by absorbing $\mathrm{H}_{2}$ via hydride forming metals and alloys at ambient temperature and releasing pure $\mathrm{H}_{2}$ when increasing the system temperature [2-5]. Compared with traditional mechanical compressors and newly developed methods, such as electrochemical and ionic liquid pistons compressors, this technology offers a lot of advantages, including simplicity in design, easy operation and repairing, compactness, safety, reliability and absence of mechanical moving parts as well as the potential ability to utilize waste industrial heat $[1,3,6]$. According to the industrial requirements of durable cycling stability and high efficiency, the hydride forming metals and alloys should satisfy the following performance features: considerable reversible hydrogen storage capacity, achievable hydrogen compression ratio from nice PCI (Pressure Composition Isotherm) properties, easy and fast hydrogenation/dehydrogenation at ambient temperature and pressure, flat plateau and narrow hysteresis, as well as easier pretreatment and activation (at less cost) [1,7]. Most importantly, the 
materials should have a good cyclic durability at extreme high temperatures and pressure conditions, and should be stable enough to not deteriorate.

Many efforts have been made by researchers around the world to find suitable hydrogen compression material from different categories of hydride, such as $\mathrm{AB}_{5}$-type [7-13], $\mathrm{AB}_{2}$-type [13-15], BCC-type [16,17], and AB-type intermetallics [18-20]. However, most of the work has focused only on hydrogenation properties at normal conditions, or cyclic compressor properties. Several reports have shown disproportionation in the alloy, resulting in the degradation of compressor performance with a number of cycles. However, no work has focused on identifying the boundary conditions for temperature and pressure, where the alloys can work without disproportionation and performance degradation. The vanadium based BCC-alloys have been extensively considered for metal hydride based hydrogen compressors worldwide due to their excellent features, i.e., high hydrogen storage capacity $(4 \mathrm{wt} \%)$ and fast kinetics for hydrogen ab/desorption at ambient temperatures [1,21-27]. Nevertheless, it is still challenging to employ these alloys for practical applications owing to difficult activation, pulverization, and bad cyclic behaviors [21,28,29]. Addition of alloying elements, such as $\mathrm{Ti}, \mathrm{Cr}, \mathrm{Fe}, \mathrm{Co}$, Mo, etc., could resolve these issues significantly [21,22,28,29].

Although the hydrogen storage properties and cyclic durability of several BCC alloys were investigated sufficiently at mild conditions [30,31], the performance under extreme conditions for hydrogen compression application has seldom been evaluated, until now. For the hydrogen compression cycling test, the actual operation condition and cyclic durability are key issues when put to practical application [1]. Recently, the cyclic performance of hydrogen ab/desorption of two different V-Ti-Cr alloys, namely $\mathrm{V}_{40} \mathrm{Ti}_{21.5} \mathrm{Cr}_{38.5}$ and $\mathrm{V}_{20} \mathrm{Ti}_{32} \mathrm{Cr}_{48}$ were systematically investigated for 100 cycles, allowing variation from the lower pressure ( $2 \mathrm{MPa}$ for $\mathrm{V}_{40} \mathrm{Ti}_{21.5} \mathrm{Cr}_{38.5}$ and $0.07 \mathrm{MPa}$ for $\mathrm{V}_{20} \mathrm{Ti}_{32} \mathrm{Cr}_{48}$ ) at room temperature to higher discharge pressure of $20 \mathrm{MPa}$ at high temperature $\left(160{ }^{\circ} \mathrm{C}\right.$ for $\mathrm{V}_{40} \mathrm{Ti}_{21.5} \mathrm{Cr}_{38.5}$ and $310{ }^{\circ} \mathrm{C}$ for $\left.\mathrm{V}_{20} \mathrm{Ti}_{32} \mathrm{Cr}_{48}\right)$ by our group [2]. The former one was found stable for cyclic hydrogen storage properties after losing $22 \%$ hydrogen storage capacity in initial ten compression cycles, whereas the hydrogen storage capacity of the latter one was decreased continuously due to the formation of thermodynamically stable monohydride phases of $\mathrm{V}$ and $\mathrm{Ti}$ [2]. In spite of disproportionation and degradation of pristine sample, $\mathrm{V}_{20} \mathrm{Ti}_{32} \mathrm{Cr}_{48}$ alloys still have larger potential to be used because of comparatively larger hydrogen storage capacity than the first one after 10 compressor cycles. In addition, lower $\mathrm{V}$ content alloy of $\mathrm{V}_{20} \mathrm{Ti}_{32} \mathrm{Cr}_{48}$, with a cheaper price, has a relevant low plateau pressure, which can achieve first stage compression easily with larger hydrogen compression ratio. Due to the above reasons, this alloy has been chosen as a model system, to know the suitable conditions to operate this alloy for hydrogen compression without disproportionation and degradation. Thus far, there is no experimental and analytical investigation methods to define the suitable boundary conditions, i.e., the temperature, pressure, and hydrogen content. Thus, the case study of $\mathrm{V}_{20} \mathrm{Ti}_{32} \mathrm{Cr}_{48}$ alloy at different extreme conditions would be helpful to generalize this method to all other hydrogen storage alloys, to define their critical conditions without disproportionation and degradation.

\section{Materials and Methods}

$\mathrm{V}_{20} \mathrm{Ti}_{32} \mathrm{Cr}_{48}$ alloy was purchased from Japan Metals and Chemicals Co., Ltd. An activation process was performed before every experiment according to the following steps: the alloy was heated to $200{ }^{\circ} \mathrm{C}$ under dynamic vacuum condition, with the heating rate of $5^{\circ} \mathrm{C} / \mathrm{min}$, and kept for $1 \mathrm{~h}$. Then, $2 \mathrm{MPa}$ pure hydrogen gas was filled in the sample cell at $200{ }^{\circ} \mathrm{C}$. The sample cell was cooled to room temperature. All of the above processes were repeated three times to make sure that the alloy was completely activated. The weight of the sample was $16.5 \mathrm{~g}$ for each experiment. A pressure composition isotherm (PCI) measurement was conducted before every hydrogen compressor cycling test at room temperature, with the maximum pressure of $6.5 \mathrm{MPa}$ using a Sieverts-type apparatus (Suzuki Shokan Co. Ltd.) at room temperature. The hydrogen compressor cycling test was performed using our homemade compressor system. A closed sample cell was filled with a certain amount of 
pure hydrogen gas according to the PCI curves. The system was heated to different temperatures with the fixed heating rate of $5{ }^{\circ} \mathrm{C} / \mathrm{min}$, followed by cooling to room temperature. This process was repeated 25 times for each condition. After a hydrogen compressor cycling test, the sample cell was vacuumed again for $2 \mathrm{~h}$ at $200{ }^{\circ} \mathrm{C}$ in order to remove the remained hydrogen gas. The PCI measurement was conducted again to check the hydrogen storage capacity and to evaluate the cyclic durability. Structural changes and phase identification were characterized by X-ray diffraction (XRD) with Rigaku-RINT 2500 equipped with $\mathrm{CuK} \alpha$ radiation. To prevent the oxidation from the air and moisture, the sample was kept in a glass plate and covered by a Kapton polyimide sheet (Du Pont-Toray Co. Ltd., Japan) for the XRD measurement. The morphology changes and composition of each sample were investigated by using Scanning Electron Microscopy (SEM) coupled with Energy-Dispersive X-ray Spectroscopy (EDS) on JEOL, JSM-6380A instrument.

\section{Results and Discussion}

In order to define the boundary conditions (critical temperature and pressure), the sorption properties and compressor cycle tests need to be performed at different points. It will identify the suitable pressure and temperature values for a particular alloy to work as hydrogen compression material without degradation. Here, the $\mathrm{V}_{20} \mathrm{Ti}_{32} \mathrm{Cr}_{48}$ alloy was investigated as a model system to obtain the best conditions without disproportionation and phase segregation, the method can be generalized for other systems later. To serve the purpose, four different points were selected as starting points according to different hydrogen content on desorption curve, namely, solid solution ( $0 \% \beta$-phase), half saturated ( $50 \% \beta$-phase), $75 \%$ saturated ( $75 \% \beta$-phase), and fully saturated $(100 \%$ $\beta$-phase). The influence of temperature at the high pressure condition and hydrogen content at the initial condition were studied in order to understand the hydrogen compressor cyclic durability by changing the operation temperature and hydrogen content, respectively.

\subsection{The Influence of Hydrogen Content on the Cyclic Durability of $\mathrm{V}_{20} \mathrm{Ti}_{32} \mathrm{Cr}_{48}$ Alloy}

For each hydrogen compressor cycling test of $\mathrm{V}_{20} \mathrm{Ti}_{32} \mathrm{Cr}_{48}$ alloy, the initial pressure of experiments was fixed in between 0.03 0.1 MPa at room temperature, as decided by PCI desorption curve Figure 1ii. Then, the sample cell was sealed by the valve and heated through a programed digital thermos heater with the heating rate of $5{ }^{\circ} \mathrm{C} / \mathrm{min}$. After the system reached to desired temperature, the sample cell was cooled down to room temperature. This whole process was treated as 1 cycle and repeated for 25 cycles. Figure $1 \mathrm{i}$ shows the data of pressure and temperature changes during 25 hydrogen compressor cycling test performed on the alloy with fully saturated $\mathrm{H}_{2}$. The maximum temperature for the test was decided as $240{ }^{\circ} \mathrm{C}$. The pressure was increased with increasing the temperature. At the first cycle, when the aimed maximum temperature reached $240^{\circ} \mathrm{C}$, the pressure also reached the maximum value of 27.8 MPa. This maximum pressure gradually reduced with number of cycles, whereas the lowest pressure at room temperature continued to increase. The other cyclic data with the different initial amount of stored hydrogen is available in Supplementary Materials Figures S1-S3. Please note: since the pressure limitation of the sample cell was below $30 \mathrm{MPa}$, we could not perform the hydrogen compressor cycling test at $260{ }^{\circ} \mathrm{C}$ for $\mathrm{V}_{20} \mathrm{Ti}_{32} \mathrm{Cr}_{48}$ alloy with fully saturated $\mathrm{H}_{2}$ content.

Figure 1ii shows the PCI curves of $\mathrm{V}_{20} \mathrm{Ti}_{32} \mathrm{Cr}_{48}$ alloy at room temperature before and after 25 compressor cycling tests (Figure 1i and Figures S1-S3) that were performed with different initial hydrogen content (b-solid solution, c-half saturated, $\mathrm{d}-75 \%$ saturated, e-fully saturated). The PCI curve, just after activated sample, shows a maximum capacity of $2.7 \mathrm{wt} \%$ with well-defined flat absorption and desorption plateau pressure at 0.4 and $0.045 \mathrm{MPa}$, respectively, Figure 1ii-a. After performing the hydrogen compressor cycling with the fully saturated hydrogen content alloy up to $240{ }^{\circ} \mathrm{C}$, Figure $1 \mathrm{i}$, the hydrogen capacity decreased significantly with a sloppy plateau region, as evidenced from the PCI curve shown in Figure 1ii-b. The behavior is quite similar for the case of cycled alloy, Figure S1, saturated $75 \%$ with hydrogen content. The total hydrogen storage capacity loss for both the above cases is found as $20.2 \%$ and $22.7 \%$, respectively. The increased slope indicated the possibility 
of multiple phases present in the sample, which dramatically reduced the hydrogen compression efficiency. On the other hand, the capacity loss is found negligible for the cycled $\mathrm{V}_{20} \mathrm{Ti}_{32} \mathrm{Cr}_{48}$ alloy, which contain less hydrogen initially, i.e., 50\% saturated and solid solution, Figure 1ii-d and ii-e. The PCI curves suggested a similar slope and stable capacity with a loss of $5.0 \%$ and $4.0 \%$, respectively, indicating the non-alteration of original hydrogen compression efficiency. Based on the above results, it can be concluded that lower hydrogen content is better for hydrogen compressor cyclic durability for $\mathrm{V}_{20} \mathrm{Ti}_{32} \mathrm{Cr}_{48}$ alloy, whereas the large amount of stored hydrogen in alloy leads to the reduction of reversible hydrogen storage capacity during hydrogen compression process for practical usage. This leads to the reduction of compression efficiency and increases the cost for maintenance.
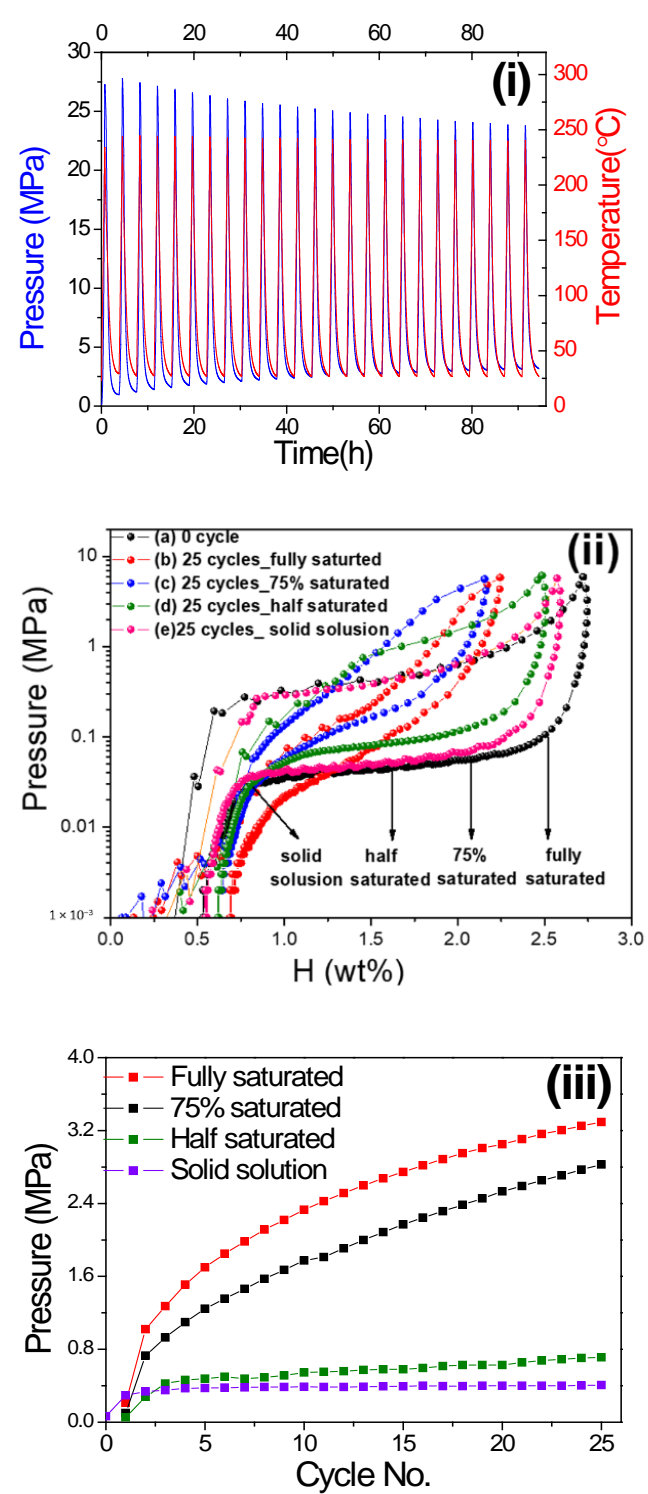

Figure 1. (i) Pressure and temperature changes during 25 cyclic compressor tests of $\mathrm{V}_{20} \mathrm{Ti}_{32} \mathrm{Cr}_{48}$ alloy with fully saturated $\mathrm{H}_{2}$ up to $240{ }^{\circ} \mathrm{C}$; (ii) pressure composition isotherm (PCI) curves of $\mathrm{V}_{20} \mathrm{Ti}_{32} \mathrm{Cr}_{48}$ alloy at room temperature(a) before and after 25 hydrogen compressor cycling tests up to high temperature (b: up to $240{ }^{\circ} \mathrm{C}$ and c, d, and e: up to $260^{\circ} \mathrm{C}$ ). The starting point was decided according to different hydrogen content: (a) solid solution, (b) half saturated, (c) 75\% saturated, (d) fully saturated; (iii) cyclic compressor performance comparison of $\mathrm{V}_{20} \mathrm{Ti}_{32} \mathrm{Cr}_{48}$ alloy with different initial hydrogen content in terms of system pressure variation at low temperature of $32.3^{\circ} \mathrm{C}$ with no. of cycles. 
To better estimate and understand the capacity degradation phenomenon, the inner pressure at lower temperature of $32{ }^{\circ} \mathrm{C}$ was collected, as the increase in inner pressure at lower temperature must be caused by residual $\mathrm{H}_{2}$ gas that could not be absorbed by the alloy in successive cycles [3]. As shown in Figure 1iii, the pressure, at a lower temperature of $32{ }^{\circ} \mathrm{C}$, increased significantly for the cycled $\mathrm{V}_{20} \mathrm{Ti}_{32} \mathrm{Cr}_{48}$ alloy, with fully saturated and $75 \%$ saturated $\mathrm{H}_{2}$, which indicated that the alloy could not absorb the same amount of $\mathrm{H}_{2}$ gas anymore and, thus, it gradually degraded. In contrast, the pressure inside the sample holder with the $\mathrm{V}_{20} \mathrm{Ti}_{32} \mathrm{Cr}_{48}$ alloy saturated with less hydrogen, i.e., $50 \%$ and $0 \%$, the pressure was very stable after the second cycle, indicating no degradation for $\mathrm{V}_{20} \mathrm{Ti}_{32} \mathrm{Cr}_{48}$ alloy under these conditions.

The structure and phase changes were investigated by X-ray diffraction. As shown in Figure 2, the pristine $\mathrm{V}_{20} \mathrm{Ti}_{32} \mathrm{Cr}_{48}$ alloy showed typical BCC structure. The cycled sample with initial lower hydrogen content (solid solution, half saturated, $75 \%$ saturated) showed similar structure as evidenced from the peaks at the same positions. However, all of the XRD peaks broadened a lot after hydrogen compressor cycles due to reduced crystal size caused by crystallite refinement during compressor cycles [31]. On the other hand, for the cycled sample initially loaded with fully saturated $\mathrm{H}_{2}$, some multiple and overlapped peaks appeared and new phases were confirmed as $\mathrm{VH}_{0.88}$ and $\mathrm{TiH}_{2}$. It is direct and obvious evidence for the disproportionation and phase separation for this sample [3]. Interestingly, according to PCI results, the sample with the initial $75 \%$ saturated $\mathrm{H}_{2}$ for hydrogen compressor at $260^{\circ} \mathrm{C}$ also showed large capacity lose, which was a sign of disproportionation. However, no big changes were observed from XRD results. Thus, it is concluded that phase separation is not the only reason for capacity fading, but the stress/strain generated in the material during the compressor test may also be responsible for this degradation [1]. More supplementary techniques are needed to clarify this issue.

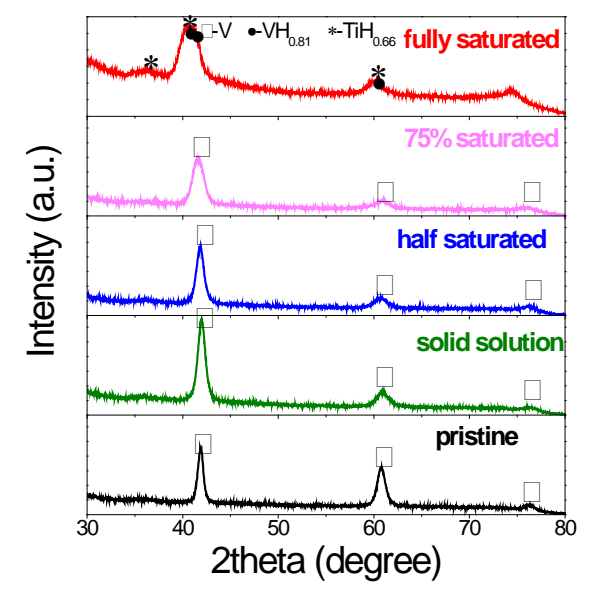

Figure 2. X-ray diffraction (XRD) profiles of $\mathrm{V}_{20} \mathrm{Ti}_{32} \mathrm{Cr}_{48}$ alloy before and after compressor cycling with different initial hydrogen content.

3.2. Temperature Influence on the Cyclic Durability of $\mathrm{V}_{20} \mathrm{Ti}_{32} \mathrm{Cr}_{48}$ Alloy with Fully Saturated Pure $\mathrm{H}_{2}$ Gas for Hydrogen Compressor

Figure 3 shows the room temperature $\mathrm{PCI}$ isotherm curves of fully saturated $\mathrm{V}_{20} \mathrm{Ti}_{32} \mathrm{Cr}_{48}$ alloy before and after 25 hydrogen compression cycling tests, up to a maximum temperature of $240{ }^{\circ} \mathrm{C}$, Figure $1 \mathrm{i} ; 200^{\circ} \mathrm{C}$, Figure $\mathrm{S} 4 ; 175^{\circ} \mathrm{C}$, Figure S5; $150^{\circ} \mathrm{C}$, Figure S6; and $100^{\circ} \mathrm{C}$, Figure S7. The PCI curves of $\mathrm{V}_{20} \mathrm{Ti}_{32} \mathrm{Cr}_{48}$ alloy with fully saturated $\mathrm{H}_{2}$ cycled for a hydrogen compressor at $240{ }^{\circ} \mathrm{C}$, Figure $1 \mathrm{i}$, clearly showed worst performance with significant hydrogen storage capacity loss up to $20.2 \%$, and increased slope, which indicated a significant reduction in reversible capacity. For the $\mathrm{V}_{20} \mathrm{Ti}_{32} \mathrm{Cr}_{48}$ alloy cycled for hydrogen compressor at $200^{\circ} \mathrm{C}$, Figure S4, the hydrogen storage capacity loss after 25 cycles was $17.9 \%$, which was a little less than the $\mathrm{V}_{20} \mathrm{Ti}_{32} \mathrm{Cr}_{48}$ alloy cycled at $240{ }^{\circ} \mathrm{C}$. Moreover, the slope of the PCI curves of this sample did not change as much as the former one. In both cases, the 
capacity loss was large enough, and could be treated as a result of disproportionation. On the other hand, $\mathrm{V}_{20} \mathrm{Ti}_{32} \mathrm{Cr}_{48}$ alloy cycled up to $175^{\circ} \mathrm{C}, 150^{\circ} \mathrm{C}$, and $100^{\circ} \mathrm{C}$, and showed little hydrogen capacity losses around $4 \%$ to $5 \%$ with similar PCI slope and stable hydrogen storage capacity. Based on the above results, it can be concluded that lower temperature is better for the compressor cyclic durability of $\mathrm{V}_{20} \mathrm{Ti}_{32} \mathrm{Cr}_{48}$ alloy, whereas higher temperature leads to the degradation of this alloy and reduces the hydrogen storage capacity during practical usage.
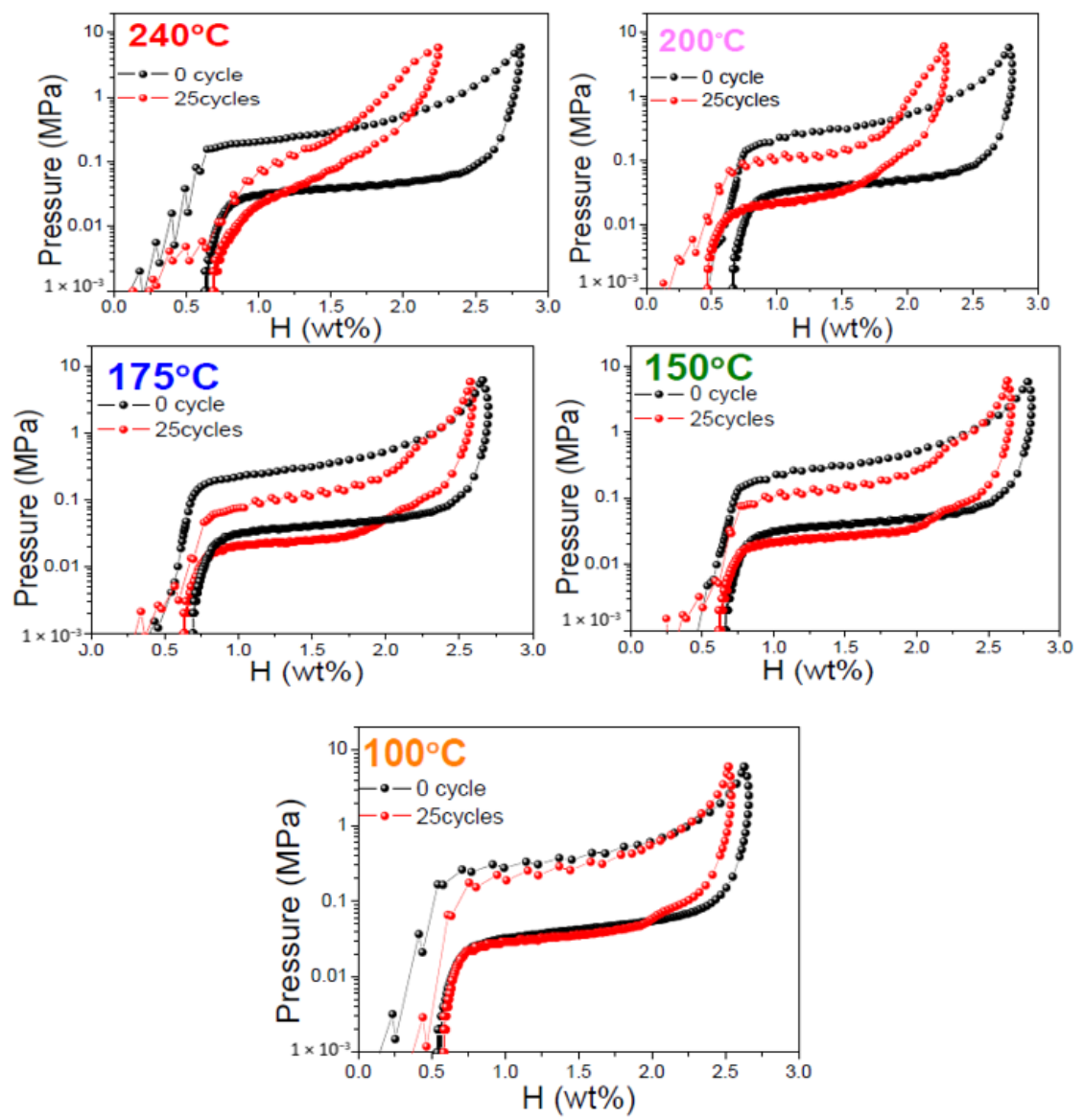

Figure 3. Comparison of pressure composition isotherm curves of $\mathrm{V}_{20} \mathrm{Ti}_{32} \mathrm{Cr}_{48}$ alloy at room temperature before and after 25 hydrogen compression cycling tests at $240{ }^{\circ} \mathrm{C}, 200^{\circ} \mathrm{C}, 175^{\circ} \mathrm{C}, 150{ }^{\circ} \mathrm{C}$, and $100{ }^{\circ} \mathrm{C}$.

In addition to the hydrogen content influence on the cyclic durability of $\mathrm{V}_{20} \mathrm{Ti}_{32} \mathrm{Cr}_{48}$ alloy, temperature impact should also not be negligible. Thus, we investigated the temperature influence on the cyclic durability for $\mathrm{V}_{20} \mathrm{Ti}_{32} \mathrm{Cr}_{48}$ alloy employed for the compressor. The maximum temperatures were chosen as $240^{\circ} \mathrm{C}, 200^{\circ} \mathrm{C}, 175^{\circ} \mathrm{C}, 150^{\circ} \mathrm{C}$, and $100^{\circ} \mathrm{C}$ for each initial hydrogen capacity, according to the desorption PCI curve, as mentioned earlier.

Similarly, the inner pressure at a lower temperature of $32.3{ }^{\circ} \mathrm{C}$ at the end of each cycle was also collected to evaluate the hydrogen compressor cycling behavior. As shown in Figure 4, for the $\mathrm{V}_{20} \mathrm{Ti}_{32} \mathrm{Cr}_{48}$ alloy hydrogen compressor cycled up to $240{ }^{\circ} \mathrm{C}$ and $200^{\circ} \mathrm{C}$, the pressure increased with the cycles, which indicated the gradual degradation of the alloy. In contrast, the $\mathrm{V}_{20} \mathrm{Ti}_{32} \mathrm{Cr}_{48}$ alloy hydrogen compressor cycled up to $175^{\circ} \mathrm{C}, 150^{\circ} \mathrm{C}$, and $100^{\circ} \mathrm{C}$; the pressure was very stable after the second cycle, indicating the stable cyclic durability during 25 cycles. 


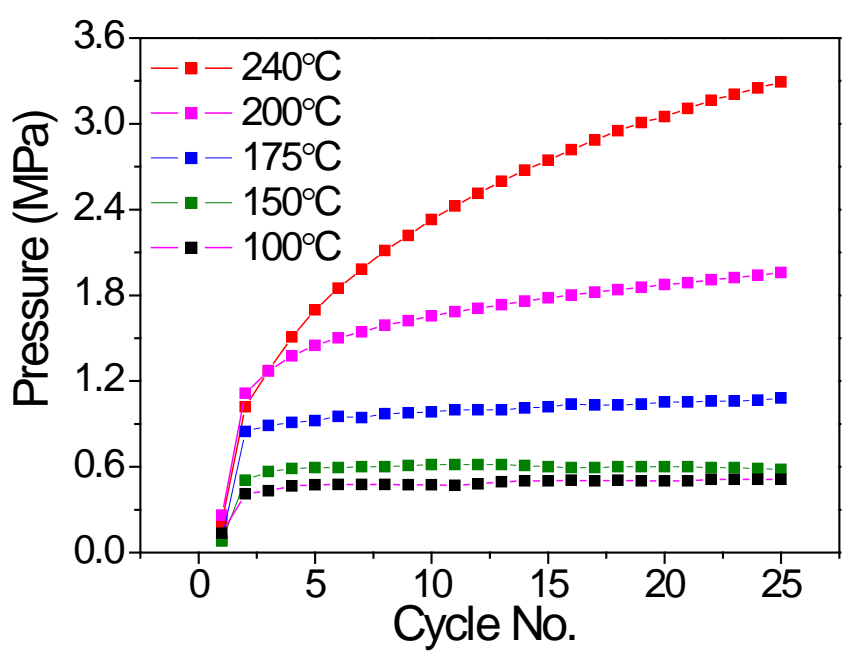

Figure 4. Cyclic compressor performance of $\mathrm{V}_{20} \mathrm{Ti}_{32} \mathrm{Cr}_{48}$ alloy with fully saturated $\mathrm{H}_{2}$ in terms of system pressure variation at low temperature of $32.3^{\circ} \mathrm{C}$ with no. of cycles.

The structural and phase changes were also investigated by X-ray diffraction. As shown in Figure 5, the pristine $\mathrm{V}_{20} \mathrm{Ti}_{32} \mathrm{Cr}_{48}$ alloy showed typical BCC structure. The samples cycled up to temperatures: $100{ }^{\circ} \mathrm{C}, 150{ }^{\circ} \mathrm{C}, 175^{\circ} \mathrm{C}$, and $200{ }^{\circ} \mathrm{C}$ showed similar structure as evidenced from the presence of peaks at the same position. However, the XRD peaks were broadened after hydrogen compressor cycles due to reduced crystallite size caused by pulverization. Moreover, the intensity of the peak at $61.02^{\circ}$ decreased, which was probably caused by the structure changes of metal matrix from BCC to the BCT structure [32-35]. On the other hand, the sample cycled at $240{ }^{\circ} \mathrm{C}$ showed multiple and overlapped peaks, which could be indexed by $\mathrm{VH}_{0.88}$ and $\mathrm{TiH}_{2}$ phases [3]. It is direct and obvious evidence for the disproportionation and phase separation, which occurred at this temperature.

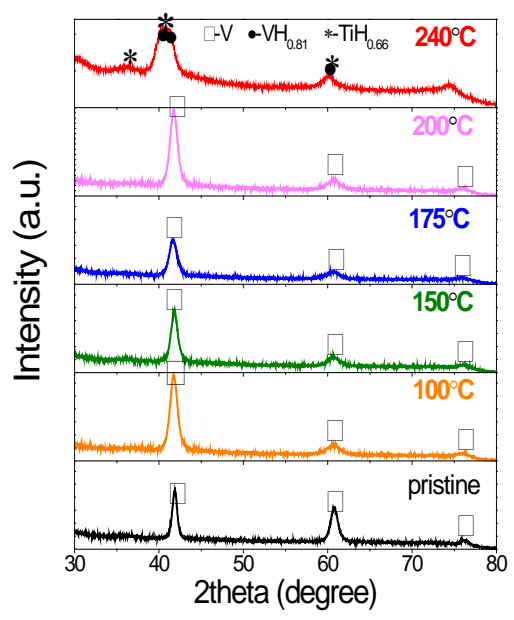

Figure 5. $\mathrm{XRD}$ of $\mathrm{V}_{20} \mathrm{Ti}_{32} \mathrm{Cr}_{48}$ alloy with fully saturated $\mathrm{H}_{2}$ after 25 hydrogen compressor cycles up to $100{ }^{\circ} \mathrm{C}, 150{ }^{\circ} \mathrm{C}, 175^{\circ} \mathrm{C}, 200{ }^{\circ} \mathrm{C}$, and $240{ }^{\circ} \mathrm{C}$.

Interestingly, according to PCI results, the sample for the hydrogen compressor at $200{ }^{\circ} \mathrm{C}$ also showed large capacity loss, which was a sign of disproportionation. However, no big changes or new phase formation could be observed from XRD results. Thus, the large capacity loss could not be explained on the basis of structural changes only, but other factors (e.g., stress/strain generation) also play an important role for this capacity loss [15].

Figure 6 shows SEM morphology of pristine and cycled (up to $240^{\circ} \mathrm{C}$ ) samples of $\mathrm{V}_{20} \mathrm{Ti}_{32} \mathrm{Cr}_{48}$ with fully saturated $\mathrm{H}_{2}$. The size of the pristine samples were not so uniform and in the range of several micrometers to hundred micrometers. After cycling, the average size of the samples was reduced, 
along with several cracks; this must have been caused by pulverization during the hydrogenation and dehydrogenation cycling processes. Moreover, point analysis was conducted by EDS to check the content of each components in $\mathrm{V}_{20} \mathrm{Ti}_{32} \mathrm{Cr}_{48}$ alloys.

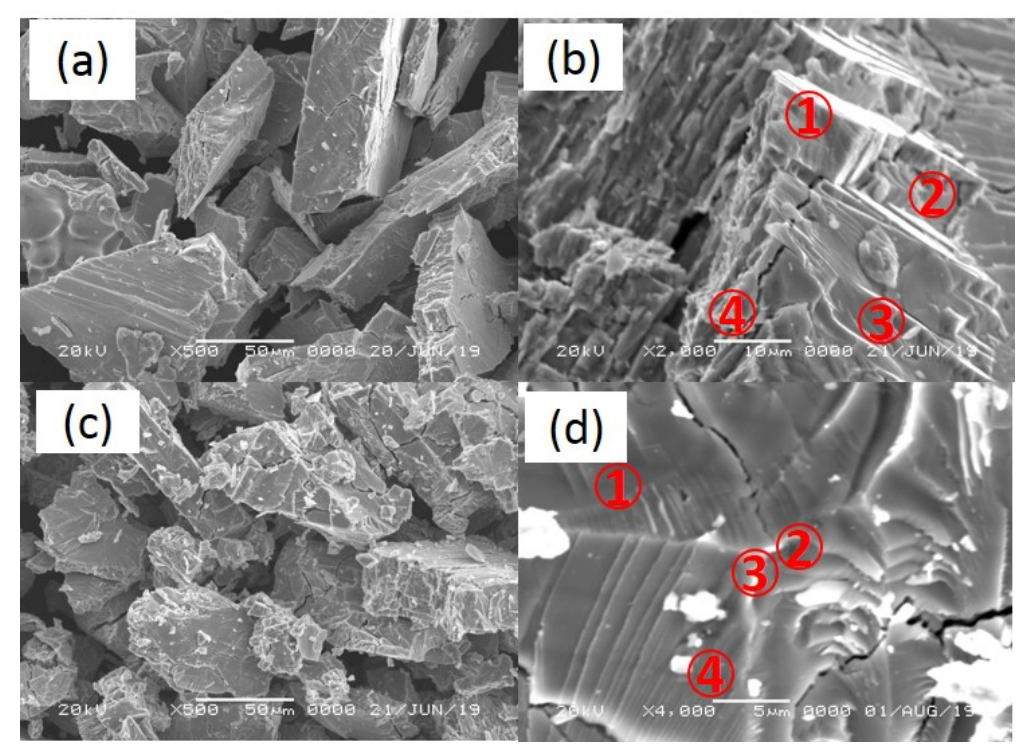

Figure 6. SEM morphology of pristine (a,b) and cycled (c,d) sample up to $240^{\circ} \mathrm{C}$ with fully saturated $\mathrm{H}_{2}$.

Table 1 shows the atomic percentage of elements in $\mathrm{V}_{20} \mathrm{Ti}_{32} \mathrm{Cr}_{48}$ alloy as determined by EDS analysis. The point no. corresponds to the different positions as shown in Figure $6 \mathrm{~b}, \mathrm{~d}$. The atomic percentage of $\mathrm{V}, \mathrm{Ti}, \mathrm{Cr}$ elements in pristine $\mathrm{V}_{20} \mathrm{Ti}_{32} \mathrm{Cr}_{48}$ alloy, as determined by EDS analysis, were very similar to the actual composition, i.e., 20,32, 48, respectively. However, after cycling, some Ti-rich phase was found, as shown in Figure 6d.

Table 1. Atomic percentage of elements in $\mathrm{V}_{20} \mathrm{Ti}_{32} \mathrm{Cr}_{48}$ alloy as determined by Energy-Dispersive $\mathrm{X}$-ray Spectroscopy (EDS) analysis. The point no. corresponds to the different positions as shown in Figure $6 \mathrm{~b}, \mathrm{~d}$.

\begin{tabular}{ccccccc}
\hline Point No. & \multicolumn{2}{c}{ V } & \multicolumn{2}{c}{ Ti } & \multicolumn{2}{c}{ Cr } \\
\hline & Pristine & Cycled & Pristine & Cycled & Pristine & Cycled \\
\hline $\mathbf{1}$ & 19.42 & 10.54 & 32.84 & 63.81 & 47.74 & 25.65 \\
$\mathbf{2}$ & 20.02 & 11.63 & 32.01 & 59.39 & 47.97 & 28.98 \\
$\mathbf{3}$ & 19.40 & 9.29 & 32.61 & 67.69 & 47.99 & 23.01 \\
$\mathbf{4}$ & 19.14 & 16.23 & 33.00 & 44.98 & 47.86 & 38.80 \\
\hline
\end{tabular}

On the basis of XRD and SEM-EDS results, a possible hypothetical qualitative reaction corresponding to the disproportionation of $\mathrm{V}_{20} \mathrm{Ti}_{32} \mathrm{Cr}_{48}$ alloy can be proposed as:

$$
\mathrm{V}_{20} \mathrm{Ti}_{32} \mathrm{Cr}_{48}+\frac{x+y}{2} \mathrm{H}_{2} \rightarrow \mathrm{V}_{20-x} \mathrm{Ti}_{32-y} \mathrm{Cr}_{48}+x \mathrm{VH}+y \mathrm{TiH}
$$

According to the above reaction, the Ti atomic percentage is increased up to more than 60 , followed by the reduction of $\mathrm{V}$ and $\mathrm{Cr}$ atomic percentage, which suggest the segregation of $\mathrm{TiH}$ phase. This clearly shows the disproportionation of $\mathrm{V}_{20} \mathrm{Ti}_{32} \mathrm{Cr}_{48}$ alloy with fully saturated $\mathrm{H}_{2}$, cycled up to $240{ }^{\circ} \mathrm{C}$.

\subsection{Summary of Hydrogen Compressor Test of $\mathrm{V}_{20} \mathrm{Ti}_{32} \mathrm{Cr}_{48}$ Alloy}

Various initial temperature and hydrogen content conditions were controlled for hydrogen compressor cycling tests of $\mathrm{V}_{20} \mathrm{Ti}_{32} \mathrm{Cr}_{48}$ alloy. The summary of all the information, such as initial 
pressure, capacity, and temperature is listed in Table S1. These results are also plotted in Figure 7a-c. The achieved max pressure and temperature were plotted in Figure 7a. As we can see, the achieved max pressure is increased with the increase in temperature, which is quite reasonable. Hydrogen content and temperature influence was checked by plotting the capacity loss (in percentage) with these two parameters. Since the amount of hydrogen left in the alloy at max temperature plays an important role in the disproportionation process, so it was calculated according to pressure, temperature, alloy amount, and sample cell volume. In order to understand the hydrogen content influence, let's have a look on Figure $7 \mathrm{~b}$. It can be clearly seen that the alloy saturated with $\mathrm{H}_{2}$ more than $75 \%$, lost significant hydrogen storage capacity $(\sim 20 \%)$, while for other cases, the capacity loss was quite small $(<8 \%)$. Thus, there is an obvious boundary between the conditions for disproportionation and cyclic stability.
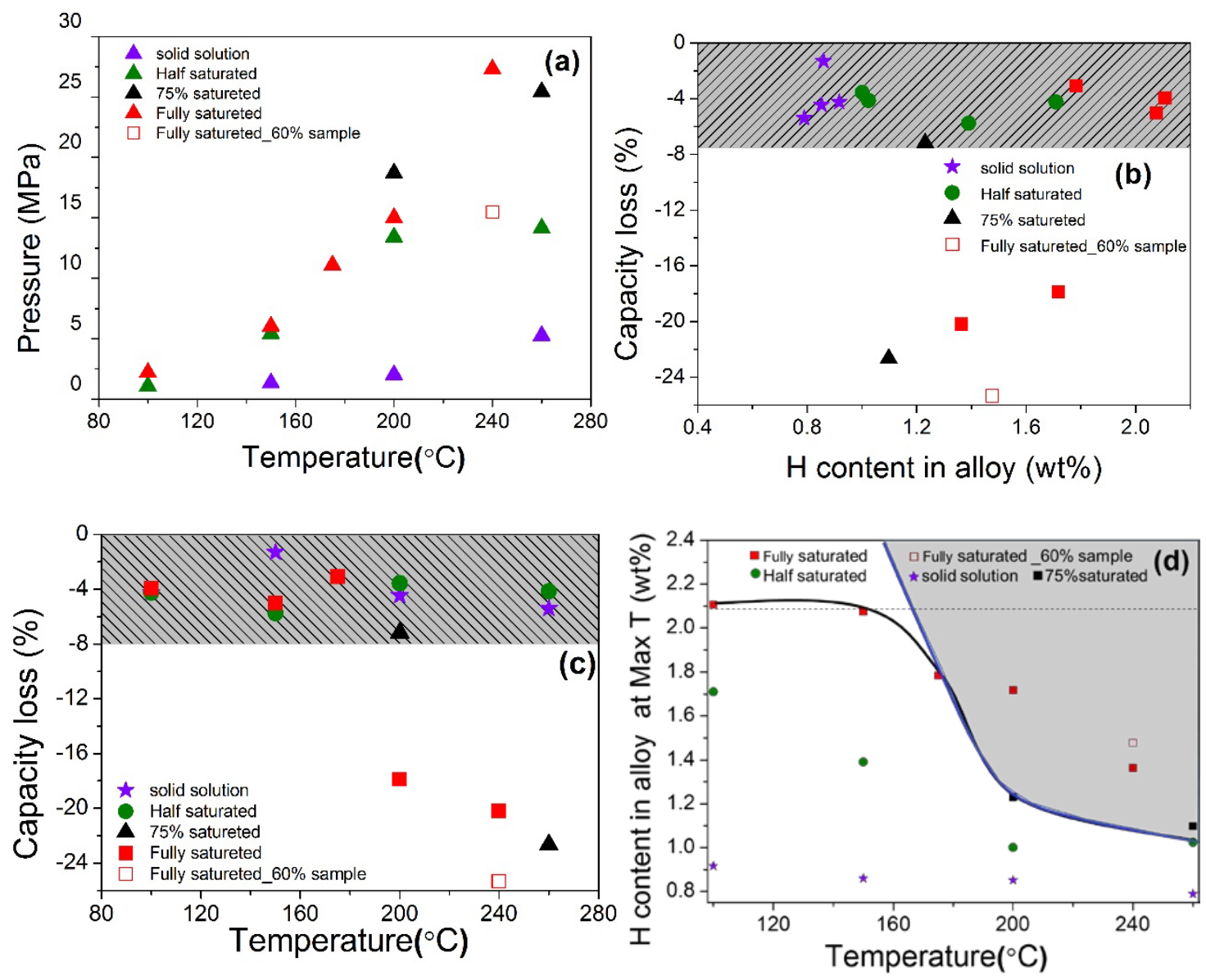

Figure 7. (a) The achieved max pressure of sample cell at maximum temperature for each hydrogen compressor cycle measurement; (b) the capacity loss of each state with the changes of $\mathrm{H}$ content remained in the alloy at high temperature; (c) the capacity loss of each state with max temperature for hydrogen compressor cycle; (d) H content remained in the alloy at achieved max temperature.

The temperature effect on the compressor cycling test is shown in Figure 7c. $\mathrm{V}_{20} \mathrm{Ti}_{32} \mathrm{Cr}_{48}$ alloys saturated with more than $75 \% \mathrm{H}_{2}$ were disproportionate at temperatures higher than $200{ }^{\circ} \mathrm{C}$, which can be considered as a boundary temperature for the disproportionation. To define a boundary line for disproportionation, the hydrogen content remained in the alloy was plotted against the maximum temperature, as shown in Figure $7 \mathrm{~d}$. At the same temperature, the sample that held more hydrogen at the initial stage before the compressor cycle test contained more hydrogen in the solid phase after reaching achieved temperature. In order to get a boundary, the black solid line was drawn based on the experimental disproportionation data by combining all of the above results, including XRD. A dashed horizontal line was drawn from experiment results in order to show the maximum hydrogen 
content that can be held by alloy. It is to be noted here that the slope line became horizontal around the remaining hydrogen content of $2.1 \mathrm{wt} \%$ due to experimental limitations, as we could not perform more experiments at more extreme conditions. If we assume that more hydrogen can remain in the alloy by applying more extreme conditions, it may cause a disproportionation even at a low temperature. It can be obtained, if the slope line (blue colored) is extended vertically upwards, as shown in the Figure $7 \mathrm{~d}$. Thus, the area covered by the horizontal and slope line through their cross (gray colored area in Figure 7d) can be a guide for suitable operating conditions for this alloy. The area left of the blue colored dashed line is suitable for this alloy, whereas the rest of the conditions will give rise to disproportionation of this alloy during cycling. If we employ this to the other alloys, it may also be fitted in a generalized way. It is important to note here that most of the alloys in general can withstand very high temperatures in the absence of hydrogen. Thus the disproportionation must be caused by the solid hydrogen present in the alloy. At $240{ }^{\circ} \mathrm{C}$, the formation of new Ti and $\mathrm{V}$ monohydride phases, as detected by XRD ( $\mathrm{TiH}_{0.66}$ and $\mathrm{VH}_{0.81}$ ) and EDS mapping (Ti-rich phase), indicated the phase segregation due to thermodynamically favored reactions, and can be the reason for disproportionation. However, it doesn't happen at lower, i.e., $200{ }^{\circ} \mathrm{C}$ and $75 \%$ hydrogen content (as observed in XRD and SEM results), which means that these hydrogenation conditions are not enough to favor the above disproportionation reaction. However, the presence of such a high hydrogen content in the alloy, as well as a high temperature, is enough to produce lattice stress/strains in the alloy, which causes the reduction in hydrogen storage capacity after the compressor cycling test. Further lowering the hydrogen content in alloy neither gives rise to the phase separation nor produces stress/strain, resulting in a stable performance with stable hydrogen storage capacity. Thus, there is a direct relation between the disproportionation, hydrogen content in the alloy, and temperature. The higher amount of hydrogen remaining in alloy leads to degradation of alloy at a much lower temperature.

\section{Conclusions}

Boundary conditions of hydrogen compressor cycle tests for $\mathrm{V}_{20} \mathrm{Ti}_{32} \mathrm{Cr}_{48}$ alloy without disproportionation was systematically investigated by changing the hydrogen content and operation temperature for the first time. Hydrogen content, as well as temperature, both play an important role in the disproportionation processes. The hydrogen content and temperature threshold of a model system, i.e., $\mathrm{V}_{20} \mathrm{Ti}_{32} \mathrm{Cr}_{48}$ alloy for the hydrogen compressor, without disproportionation, were identified as $75 \%$ and $200{ }^{\circ} \mathrm{C}$, respectively. A clear disproportionation area was drawn for the first time, which can be used as guidance for safe usage of $\mathrm{V}_{20} \mathrm{Ti}_{32} \mathrm{Cr}_{48}$ alloy for hydrogen compressor application. The amount of hydrogen in the alloy is inversely proportional to the required temperature for degradation. This methodology can be applied to the other materials to identify the critical conditions required for safer and stable operation during compressor cycling.

Supplementary Materials: The following are available online at http://www.mdpi.com/1996-1073/13/9/2324/s1, Figure S1: Pressure and temperature changes for 25 cyclic compressor tests of $\mathrm{V}_{20} \mathrm{Ti}_{32} \mathrm{Cr}_{48}$ alloy with $75 \%$ saturated $\mathrm{H}_{2}$ up to a maximum temperature of $260^{\circ} \mathrm{C}$. Figure S2: Pressure and temperature changes for 25 cyclic compressor tests of $\mathrm{V}_{20} \mathrm{Ti}_{32} \mathrm{Cr}_{48}$ alloy with $50 \%$ saturated $\mathrm{H}_{2}$ up to a maximum temperature of $260{ }^{\circ} \mathrm{C}$. Figure S3: Pressure and temperature changes for 25 cyclic compressor tests of $\mathrm{V}_{20} \mathrm{Ti}_{32} \mathrm{Cr}_{48}$ alloy with solid solution of $\mathrm{H}_{2}$ up to a maximum temperature of $260{ }^{\circ} \mathrm{C}$. Figure S4: Pressure and temperature changes for 25 cyclic compressor tests of $\mathrm{V}_{20} \mathrm{Ti}_{32} \mathrm{Cr}_{48}$ alloy with $100 \%$ saturated $\mathrm{H}_{2}$ up to a maximum temperature of $200{ }^{\circ} \mathrm{C}$. Figure S5: Pressure and temperature changes for 25 cyclic compressor tests of $\mathrm{V}_{20} \mathrm{Ti}_{32} \mathrm{Cr}_{48}$ alloy with $100 \%$ saturated $\mathrm{H}_{2}$ up to a maximum temperature of $175^{\circ} \mathrm{C}$. Figure S6: Pressure and temperature changes for 25 cyclic compressor tests of $\mathrm{V}_{20} \mathrm{Ti}_{32} \mathrm{Cr}_{48}$ alloy with $100 \%$ saturated $\mathrm{H}_{2}$ up to a maximum temperature of $150{ }^{\circ} \mathrm{C}$. Figure S7: Pressure and temperature changes for 25 cyclic compressor tests of $\mathrm{V}_{20} \mathrm{Ti}_{32} \mathrm{Cr}_{48}$ alloy with $100 \%$ saturated $\mathrm{H}_{2}$ up to a maximum temperature of $100{ }^{\circ} \mathrm{C}$. Table S1: Summary of detailed parameters for hydrogen compressor cycling test for $\mathrm{V}_{20} \mathrm{Ti}_{32} \mathrm{Cr}_{48}$ alloy at various conditions.

Author Contributions: Conceptualization, T.I.; methodology, A.J. and H.M.; validation, A.J.; formal analysis, F.G.; investigation, F.G.; resources, Y.K.; data curation, F.G. and T.I.; writing, F.G.; writing-review and editing, A.J. and T.I.; supervision, A.J. and T.I. All authors have read and agreed to the published version of the manuscript.

Funding: This research received no external funding. 
Acknowledgments: Authors would like to thanks Tomoyuki Ichikawa for his technical help in preparation of the sample holder for high pressure measurement as well as data acquisition.

Conflicts of Interest: The authors declare no conflict of interest.

\section{References}

1. Lototsky, M.V.; Yartys, V.A.; Pollet, B.G.; Bowman, R.C., Jr. Metal hydride hydrogen compressors: A review. Int. J. Hydrogen Energy 2014, 39, 5818-5851. [CrossRef]

2. Tsurui, N.; Goshome, K.; Hino, S.; Endo, N.; Maeda, T.; Miyaoka, H.; Ichikawa, T. Hydrogen Desorption Isobar Properties of $\mathrm{Ti}_{1.1} \mathrm{CrMn}$ at High Temperatures and Pressures. J. Jpn. Inst. Metals 2018, 59, 855-857.

3. Selvaraj, S.; Jain, A.; Kumar, S.; Zhang, T.; Isobe, S.; Miyaoka, H.; Kojima, Y.; Ichikawa, T. Study of cyclic performance of V-Ti-Cr alloys employed for hydrogen compressor. Int. J. Hydrogen Energy 2018, 43, 2881-2889. [CrossRef]

4. Pickering, L.; Reed, D.; Bevan, A.I.; Book, D. Ti-V-Mn based metal hydrides for hydrogen compression applications. J. Alloys Compd. 2015, 645, S400-S403. [CrossRef]

5. Wang, X.; Liu, H.; Li, H. A $70 \mathrm{MPa}$ hydrogen-compression system using metal hydrides. Int. J. Hydrogen Energy 2011, 36, 9079-9085. [CrossRef]

6. Yartys, V.A.; Lototskyy, M.; Linkov, V.; Grant, D.; Stuart, A.; Eriksen, J.; Denys, R.; Bowman, R.C., Jr. Metal hydride hydrogen compression: Recent advances and future prospects. J. Alloys Compd. 2016, 122, 415. [CrossRef]

7. Tarasov, B.P.; Bocharnikov, M.S.; Yanenko, Y.B.; Fursikov, P.V.; Lototskyy, M.V. Cycling stability of RNi $(\mathrm{R}=\mathrm{La}, \mathrm{La}+\mathrm{Ce})$ hydrides during the operation of metal hydride hydrogen compressor. Int. J. Hydrogen Energy 2018, 43, 4415-4427. [CrossRef]

8. Bocharnikov, M.S.; Yanenko, Y.B.; Tarasov, B.P. Metal hydride thermosorption compressor of hydrogen high pressure. Int. Sci. J. Altern. Energy Ecol. ISJAEE 2012, 12, 18-23.

9. Odysseos, M.; De Rango, P.; Christodoulou, C.N.; Hlil, E.K.; Steriotis, T.; Karagiorgis, G.; Charalambopoulou, G.; Papapanagiotou, T.; Ampoumogli, A.; Psycharis, V.; et al. The effect of compositional changes on the structural and hydrogen storage properties of (La-Ce) $\mathrm{Ni}_{5}$ type intermetallics towards compounds suitable for metal hydride hydrogen compression. J. Alloys Compd. 2013, 580, S268-S270. [CrossRef]

10. Wang, X.; Chen, R.; Zhang, Y.; Chen, C.; Wang, Q. Hydrogen storage properties of (La-Ce-Ca) Ni ${ }_{5}$ alloys and application for hydrogen compression. Mater Lett. 2007, 61, 1101-1104. [CrossRef]

11. Hopkins, R.R.; Kim, K.J. Hydrogen compression characteristics of a dual stage thermal compressor system utilizing $\mathrm{LaNi}_{5}$ and $\mathrm{Ca}_{0.6} \mathrm{Mm}_{0.4} \mathrm{Ni}_{5}$ as the working metal hydrides. Int. J. Hydrogen Energy 2010, 35, 5693-5702. [CrossRef]

12. Luo, G.; Chen, J.P.; Li, S.L.; Chen, W.; Han, X.B.; Chen, D.M.; Yang, K. Properties of $\mathrm{La}_{0.2} \mathrm{Y}_{0.8} \mathrm{Ni}_{5-\mathrm{x}} \mathrm{Mn}_{\mathrm{x}}$ alloys for high-pressure hydrogen compressor. Int. J. Hydrogen Energy 2010, 35, 8262-8267. [CrossRef]

13. Li, H.; Wang, X.H.; Dong, Z.H.; Xu, L.; Chen, C.P. A study on 70MPa metal hydride hydrogen compressor. J. Alloys Compd. 2003, 502, 503-507. [CrossRef]

14. Shilov, A.L.; Padurets, L.N.; Kost, M.E. Thermodynamics of hydrides of intermetallic compounds of transition metals. Russ. J. Phys. Chem. 1985, 59, 1857-1875.

15. Zotov, T.A.; Sivov, R.B.; Movlaev, E.A.; Mitrokhin, S.V.; Verbetsky, V.N. IMC hydrides with high hydrogen dissociation pressure. J. Alloys Compd. 2011, 509S, S839-S843. [CrossRef]

16. Bowman, R.C., Jr.; Freeman, B.D.; Phillips, J.R. Evaluation of metal hydride compressors for applications in Joule-Thomson cryocoolers. Cryogenics 1992, 32, 127-138. [CrossRef]

17. Reilly, J.J.; Holtz, A.; Wiswall, R.H., Jr. A new laboratory gas circulation pump for intermediate pressures. Rev. Sci. Instr. 1971, 42, 1485-1486. [CrossRef]

18. Williams, M.; Lototsky, M.V.; Davids, M.W.; Linkov, V.; Yartys, V.A.; Solberg, J.K. Chemical surface modification for the improvement of the hydrogenation kinetics and poisoning resistance of TiFe. J. Alloys Compd. 2011, 509S, 770-774. [CrossRef]

19. Sandrock, G. A panoramic overview of hydrogen storage alloys from a gas reaction point of view. J. Alloys Compd. 1999, 293-295, 877-888. [CrossRef]

20. Wiswall, R.H.; Reilly, J.J. Method of Storing Hydrogen. U.S. Patent 351, 23 June 1970. 
21. Kumar, S.; Jain, A.; Ichikawa, T.; Kojima, Y.; Dey, G.K. Development of vanadium based hydrogen storage material: A review. Renew. Sustain. Energy Rev. 2017, 72, 791-800. [CrossRef]

22. Veleckis, E.; Edwards, R.K. Thermodynamic Properties in the Systems V-H, Nb-H, and Ta-H Thermodynamic Properties in the Systems Vanadium-Hydrogen, Niobium-Hydrogen, and Tantalum-Hydrogen. J. Phys. Chem. C 1969, 73, 683-692. [CrossRef]

23. Lototsky, M.V.; Yartys, V.A.; Zavaliy, I.Y. Vanadium-based BCC alloys: Phase-structural characteristics and hydrogen sorption properties. J. Alloys Compd. 2005, 404-406, 421-426. [CrossRef]

24. Yukawa, H.; Takagi, M.; Teshima, A.; Morinaga, M. Alloying effects on the stability of vanadium hydrides. J. Alloys Compd. 2002, 330-332, 105-109. [CrossRef]

25. Yukawa, H.; Yamashita, D.; Ito, S.; Morinaga, M.; Yamaguchi, S. Compositional dependence of hydriding properties of vanadium alloys at low hydrogen pressures. J. Alloys Compd. 2003, 356-357, 45-49. [CrossRef]

26. Kumar, S.; Taxak, M.; Krishnamurthy, N. Hydrogen absorption kinetics of $\mathrm{V}_{4} \mathrm{Cr}_{4} \mathrm{Ti}$ alloy prepared by aluminothermy. Int. J. Hydrogen Energy 2012, 37, 3283-3291. [CrossRef]

27. Peterson, D.T.; Nelson, S.O. Isopiestic Solubility of Hydrogen in Vanadium Alloys at Low Temperatures. Metall. Mater. Trans. A 1985, 16,367-374. [CrossRef]

28. Kumar, S.; Krishnamurthy, N. Effect of aluminum on solubility and $\beta$ phase stability of vanadium-hydrogen system. Int. J. Refract. Met. Hard Mater. 2012, 35, 191-195. [CrossRef]

29. Sanjay, K.; Tiwari, G.P.; Krishnamurthy, N. Tailoring the hydrogen desorption thermodynamics of $\mathrm{V}_{2} \mathrm{H}$ by alloying additives. J. Alloy Compd. 2015, 645, S252-S256.

30. Itoh, H.; Arashima, H.; Kubo, K.; Kabutomori, T.; Ohnishi, K. Improvement of cyclic durability of BCC structured Ti-Cr-V alloys. J. Alloys Compd. 2005, 404-406, 417-420. [CrossRef]

31. Shen, C.C.; Li, H.C. Cyclic hydrogenation stability of $\gamma$-hydrides for $\mathrm{Ti}_{25} \mathrm{~V}_{35} \mathrm{Cr}_{40}$ alloys doped with carbon. J. Alloys Compd. 2015, 648, 534-539. [CrossRef]

32. Selvaraj, S.; Jain, A.; Miyaoka, H.; Kojima, Y.; Ichikawa, T. Hydrogen Sorption and Cyclic Compressor Performance of $\mathrm{V}_{40} \mathrm{Ti}_{21.5} \mathrm{Cr}_{33.5} \mathrm{M}_{5}(\mathrm{M}=\mathrm{Nb}, \mathrm{Zr}, \mathrm{Fe})$ Alloys. J. Jpn. Inst. Energy 2019, 98, 157-164. [CrossRef]

33. Kim, H.; Sakai, K.; Ogawa, H.; Nakamura, Y.; Nakamura, J.; Akiba, E.; Machida, A.; Watanuki, T.; Proffen, T. Origin of Degradation in the Reversible Hydrogen Storage Capacity of $\mathrm{V}_{1-\mathrm{x}} \mathrm{Ti}_{\mathrm{x}}$ Alloys from the Atomic Pair Distribution Function Analysis. J. Phys. Chem. C 2013, 117, 26543-26550. [CrossRef]

34. Plante, D.; Andrieux, J.; Laversenne, L.; Miraglia, S. In situ X-Ray diffraction study of hydrogen sorption in V-rich Ti-V-Cr bcc solid solutions. J. Alloys Compd. 2015, 648, 79-85. [CrossRef]

35. Tsukahara, M. Hydrogenation Properties of Vanadium-Based Alloys with Large Hydrogen Storage Capacity. Mater. Trans 2011, 52, 68-72. [CrossRef]

(C) 2020 by the authors. Licensee MDPI, Basel, Switzerland. This article is an open access article distributed under the terms and conditions of the Creative Commons Attribution (CC BY) license (http://creativecommons.org/licenses/by/4.0/). 